\title{
In vivo threonine oxidation in growing pigs fed on diets with graded levels of threonine*
}

\author{
BY N. LE FLOC'H ${ }^{1}$, C. OBLED ${ }^{2}$ AND B. SÈVE ${ }^{1}$ \\ ${ }^{1}$ Station de Recherches Porcines, INRA, 35590 Saint Gilles, France \\ ${ }^{2}$ Laboratoire d'Étude du Métabolisme Azoté, INRA, 63122 Ceyrat, France
}

(Received 16 June 1995 - Revised 14 September 1995 - Accepted 6 October 1995)

\begin{abstract}
Threonine oxidation to glycine was investigated in vivo in twelve growing pigs ( $27.4 \mathrm{~kg}$ live weight) fed on one of the following three diets with graded levels of threonine supply: a low-threonine diet (LT), a control well-balanced diet (C) or a high-threonine diet (HT), during $10 \mathrm{~h}$ constant infusion of $\mathrm{L}-\left[1-{ }^{13} \mathrm{C}\right]$ threonine and $\left[2-{ }^{3} \mathrm{H}\right] \mathrm{glycine}$ in the cranial vena cava and $\left[1-{ }^{14} \mathrm{C}\right] \mathrm{glycine}$ in the portal vein. ${ }^{13} \mathrm{C}$-threonine and glycine enrichments and $\left[{ }^{3} \mathrm{H}\right]$ glycine and $\left[{ }^{14} \mathrm{Clglycine}\right.$ specific radioactivities (SR) were determined at plateau in peripheral venous plasma, liver and pancreas. Glycine production rates calculated from plasma $\left[2-{ }^{3} \mathrm{H}\right]$ glycine or $\left[1-{ }^{14} \mathrm{C}\right]$ glycine $S R$ gave similar values suggesting that $\left[1-{ }^{14} \mathrm{C}\right.$ glycine SR could be used in order to estimate whole-body glycine flux. The high pancreas $\left[1-{ }^{13} \mathrm{Clglycine}\right.$ enrichment provided evidence that the pancreas may be, with the liver, a major site of threonine oxidation to glycine. Moreover, the present findings suggest that threonine transport into the liver could be the limiting step of threonine oxidation in this tissue when dietary threonine supply is low. Total threonine oxidation to glycine, calculated from plasma values of enrichment and specific radioactivity, was low and constant when the estimated absorbed threonine was lower than $4 \mathrm{~g} / \mathrm{d}$ and increased for higher amounts of absorbed threonine.
\end{abstract}

Pigs: Threonine: Oxidation

Threonine is an essential amino acid and its oxidation represents an irreversible loss for body protein because it cannot be synthesized de novo. Moreover, in pigs, threonine supply is often limiting for maintenance and growth (Fuller et al. 1989). Consequently, an adequate supply of dietary threonine is crucial to maintain protein synthesis and deposition. The measurement of threonine oxidation could be used to calculate threonine requirement. Indeed, in rats, Kang-Lee \& Harper (1978) reported that the change of threonine oxidation according to threonine intake showed a break point near the requirement level. Moreover, threonine oxidation measurement provides a direct estimate for threonine deposition, calculated as the difference between threonine intake and threonine oxidation, and for dietary threonine efficiency for body protein deposition in different nutritional situations. The infusion of labelled amino acid is used to study threonine oxidation in vivo over a short time period without using $\mathrm{N}$ balance or comparative slaughter techniques.

Threonine is oxidized through two degradative pathways: (1) threonine dehydratase (EC 4.2.1.16; TDH) catabolizes threonine into 2-ketobutyric acid and $\mathrm{NH}_{4}{ }^{+}$(Freedland \& Avery, 1964); (2) threonine is also oxidized by L-threonine 3-dehydrogenase (EC 1.1.1.103; TDG) to yield 2-amino 3-ketobutyric acid, which spontaneously decarboxylates to give amino acetone, or glycine and acetyl CoA when TDG is coupled with 2-amino 3-ketobutyrate CoA ligase (EC 2.3.1.29) (Dale, 1978; Bird et al. 1984).

* Presented in part at the VII Symposium on Protein Metabolism and Nutrition, May 24-27 1995, Estaçao Zootécnica Nacional, Vale de Santarem, Portugal. 
Threonine oxidation in vivo has usually been determined by measuring the production of labelled $\mathrm{CO}_{2}$ during the infusion of threonine labelled on its carboxyl group (Chavez \& Bayley, 1976; Kang-Lee \& Harper, 1978; Egan et al. 1983; Zhao et al. 1986). However, the measurement of labelled $\mathrm{CO}_{2}$ underestimates threonine oxidation because of the sequestration of two $\mathrm{C}$ atoms of threonine into glycine. Moreover, this method does not allow for the partitioning of threonine oxidation between the two degradative pathways. These were the reasons why a multitracer method was developed and validated in pigs by Ballèvre et al. $(1990,1991$ a). Thus, in fed pigs it was shown that more than $80 \%$ of threonine oxidation occurred through glycine production and that the contribution of TDH as a gluconeogenic pathway from threonine was probably minor.

An accurate estimation of threonine oxidation by the multitracer infusion technique is possible only when the precursor pool for oxidation is well defined. In pigs it has been assumed that threonine oxidation to glycine takes place only in the liver (Ballèvre et al. 1990). In this case the precursor pool for threonine oxidation is represented by intrahepatic threonine. Nevertheless, le Floc'h et al. (1995) have suggested that, when threonine dietary supply is limiting, an important part of threonine oxidation could be extrahepatic. Moreover, since glycine portal infusion did not allow the infusion of hepatic tissue, threonine oxidation through the TDG pathway was calculated from plasma data. The present experiment was designed to reassess threonine oxidation to glycine, comparing two sites of labelled glycine infusion for the measurement of whole-body glycine flux. Furthermore, the respective contributions of hepatic and extrahepatic tissues to threonine oxidation to glycine were investigated at three levels of threonine supply, including one in excess of the requirement.

\section{MATERIALS AND METHODS}

\section{Chemicals}

$\mathrm{L}-\left[1-{ }^{13} \mathrm{C}\right]$ Threonine and $\left[1-{ }^{13} \mathrm{C}\right]$ glycine were provided by Tracer Technologies (Somerville, MA, USA). Their enrichment was $>99 \%$. $\left[1-{ }^{14} \mathrm{C}\right] \mathrm{Glycine}(1.85 \mathrm{GBq} / \mathrm{mmol})$ and [2${ }^{3} \mathrm{H}$ ]glycine (1.48 TBq/mmol) were purchased from ICN France (Orsay, France). All other chemicals were purchased from either Sigma (St Louis, MO, USA), Merck (Darmstadt, Germany) or Boehringer (Mannheim, Germany) and were of analytical grade.

\section{Animals and diets}

Twelve female Pietrain $\times$ Large White pigs from the INRA herd, at a starting weight of 22.8 (SE 0.23) kg, were allocated to three experimental groups. The basal diet (Table 1) was composed of a mixture of wheat, soyabean meal, peanut meal and wheat-gluten meal. Adequate supplements of free amino acids were added to meet the requirement for essential amino acids according to the recommendations of Baker \& Chung (1992). Threonine contents of the diets were adjusted by addition of graded levels of free L-threonine at the expense of maize starch in order to maintain the same crude protein $(\mathrm{CP}=\mathrm{N} \times 6.25)$ content of $15.5 \%$ in the three diets. Free L-threonine supplements were $0.4,1.63$ and $2.8 \mathrm{~g} / \mathrm{kg}$ diet for the threonine-deficient diet (LT), the control well-balanced diet (C) and the high-threonine diet (HT) respectively. Total threonine contents of the experimental diets were $4 \cdot 71,5.94$ and $7 \cdot 11 \mathrm{~g} / \mathrm{kg}$ for the LT, C and HT diets respectively. After 1 week of adaptation to the experimental diets, pigs were surgically prepared as follows. Two catheters were introduced into the cranial vena cava through each jugular vein: the left one was used for blood sampling and the right one, which was $50 \mathrm{~mm}$ longer than the left one, was used for tracer infusion. A third catheter was introduced in the portal vein for [1${ }^{14} \mathrm{C}$ ]glycine infusion. The three catheters were aseptically rinsed every day with heparinized 
Table 1. Composition of experimental diets $(\mathrm{g} / \mathrm{kg})$

\begin{tabular}{ll}
\hline \hline Ingredients & \\
\hline Wheat $(121 \mathrm{~g} \mathrm{CP} / \mathrm{kg})$ & 725 \\
Soyabean meal $(451 \mathrm{~g} \mathrm{CP} / \mathrm{kg})$ & 20 \\
Peanut meal $(500 \mathrm{~g} \mathrm{CP} / \mathrm{kg})$ & 80 \\
Wheat-gluten meal $(822 \mathrm{~g} \mathrm{CP} / \mathrm{kg})$ & 15 \\
Maize starch* & $80 \cdot 4 / 79 \cdot 17 / 78 \cdot 0$ \\
Sugar-cane molasses & 30 \\
Dicalcium phosphate & 20 \\
Limestone & 12 \\
Iodized salt & $3 \cdot 5$ \\
Potassium carbonate & 2 \\
Trace mineral and vitamin premix $\dagger$ & 5 \\
L-Lysine HCl & $5 \cdot 7$ \\
L-Threonine* & $0 \cdot 4 / 1 \cdot 63 / 2 \cdot 8$ \\
DL-Methionine & $0 \cdot 5$ \\
\hline \hline
\end{tabular}

$\mathbf{C P}$, crude protein.

* The three experimental diets, LT, C and HT, were obtained after supplementary addition of 0.4, 1.63 and $2.8 \mathrm{~g}$ L-threonine/ $\mathrm{kg}$ respectively, at the expense of maize starch $(80 \cdot 4,79 \cdot 17$ and 78 for LT, C and HT diets respectively.

$\dagger$ Provided the following amounts of trace elements and vitamins (mg/kg diet): $\mathrm{Fe} \mathrm{40,} \mathrm{Cu} \mathrm{S,} \mathrm{Zn} \mathrm{50,} \mathrm{Mn} \mathrm{20,}$ Co 0.05, I 0.3, Se 0.075, retinyl palmitate 5, cholecalciferol 1, all-rac- $\alpha$-tocopheryl acetate 5, menadione 1 , thiamin 1 , riboflavin 2 , niacin 7.5 , Ca pantothenate 5 , pyridoxine 0.5 , cyanocobalamin 0.01 , pteroylmonoglutamic acid $0 \cdot 5$, biotin 0.1 , choline chloride 100 , ground wheat was used as a carrier.

$\ddagger$ Contained $785 \mathrm{~g}$ lysine $/ \mathbf{k g}$.

saline. The food was available hourly, in twenty-four equal meals, from an automatic feeder. About $5 \mathrm{~d}$ before the infusion, total urine and faeces were collected for $\mathrm{N}$ balance measurement. Urine was collected into $0.05 \mathrm{M}-\mathrm{H}_{2} \mathrm{SO}_{4}$. At $14 \mathrm{~h}$ before starting the infusion, diets were replaced by 'infusion' diets which contained $7 \%$ less threonine in order to compensate for threonine supplied by continuous infusion of labelled amino acids and to maintain threonine deficiency, adequacy or excess. The research was conducted under the guidelines of the French Ministry of Agriculture for experiments on animals.

\section{Infusion protocol}

About $10 \mathrm{~d}$ after surgical preparation, $\mathrm{L}-\left[1-{ }^{13} \mathrm{C}\right]$ threonine, $\left[1-{ }^{14} \mathrm{C}\right]$ glycine and $\left[2-{ }^{3} \mathrm{H}\right]$ glycine were infused for $10 \mathrm{~h}$ at the rate of 12.03 (SE 0.04 ) $\mu \mathrm{mol} / \mathrm{kg}$ per h, 4.55 (SE 0.12 ) kBq $/ \mathrm{kg}$ per $\mathrm{h}$ and $38.5(\mathrm{sE} 0.8) \mathrm{kBq} / \mathrm{kg}$ per $\mathrm{h}$ respectively. $\mathrm{L}-\left[1-{ }^{13} \mathrm{C}\right] \mathrm{Threonine}$ and $\left[2-{ }^{3} \mathrm{H}\right]$ glycine were infused through the jugular catheter and $\left[1{ }^{14} \mathrm{C}\right] \mathrm{glycine}$ through the portal catheter. Before the beginning of the infusion, one blood and one urine sample were obtained for basal enrichment determination and primary and secondary pools were primed with a bolus injection of $10 \mathrm{ml}$ saline providing 12.3 (SE 0.1) $\mu \mathrm{mol} \mathrm{L-}\left[1{ }^{13} \mathrm{C}\right]$ threonine $/ \mathrm{kg}, 1.3$ (SE $0.07) \mu \mathrm{mol}\left[1-{ }^{13} \mathrm{C}\right]$ glycine $/ \mathrm{kg}$ per $\mathrm{h}$ and 4.19 (SE 0.24) $\mathrm{kBq}\left[1-{ }^{14} \mathrm{C}\right]$ glycine $/ \mathrm{kg}$. Blood $(50 \mathrm{ml})$ was sampled every 30 min during the last $2 \mathrm{~h}$ of infusion and centrifuged for plasma separation. Before the end of the period of infusion the pig was anaesthetized with pentobarbital. Liver and pancreas were quickly removed after laparotomy, frozen in liquid $\mathrm{N}_{2}$ and kept at $-80^{\circ}$ before analysis. Urine was collected directly from the bladder and kept at $-20^{\circ}$. Then, the infusion was stopped and pigs were killed by exsanguination. 


\section{Analytical procedure}

Urine and faeces were collected during $4 \mathrm{~d}$ before the infusion and total $\mathrm{N}$ content of urine and faeces was determined by the Dumas method (Leco FP428; St Joseph, MI, USA). Plasma and liver amino acid concentrations were determined as described previously (Le Floc'h et al. 1994). For enrichment and specific radioactivity determinations, plasma $(1: 8 \mathrm{v} / \mathrm{v})$ and liver $(1: 8 \mathrm{w} / \mathrm{w})$ were homogenized in TCA $(100 \mathrm{~g} / \mathrm{l})$ and centrifuged. Amino acids from the supernatant fractions were purified through cation exchange resin (AG 50W-X8, 100-200 mesh; Biorad, Richmond, CA, USA). Glycine from urine was obtained from hippurate (HA) after acid hydrolysis as described by Ballèvre et al. (1990).

Glycine from urine, plasma and tissues was purified by liquid chromatography (Multichrom amino acid analyser, Beckman, München, Germany). Glycine was then eluted with a sodium citrate buffer and collected with a fraction collector (Gilson 202; Villiers Le Bel, France). Collected fractions were pooled and radioactivity was measured by liquid scintillation counting (Ionic Fluor; Packard, Downers Grove, IL, USA) on a liquid scintillation analyser (Tri-carb 1600 TR; Packard). Glycine concentration in the pooled fractions was measured by liquid chromatography. Specific radioactivity was calculated as the counted radioactivity: glycine concentration ratio in the collected pool.

Glycine ${ }^{13} \mathrm{C}$ enrichments were determined in plasma, liver and urine after purification by preparative chromatography as described above, except that plasma and liver amino acid extracts were enzymically treated by alanine dehydrogenase $(E C 1.4 .1 .1)$ as previously described (Ballèvre et al. 1991 a) in order to avoid liver glycine contamination by alanine. $\left[2-{ }^{14} \mathrm{C}\right]$ Glycine $(1 \mathrm{kBq})$ was added in each sample, so that glycine could be located by continuous flow detection of radioactivity (Flo-one $\beta$; Radiomatic Instrument, La Queue Les Yvelines, France). The ${ }^{13} \mathrm{C}$ enrichment on the first $\mathrm{C}$ of glycine was determined from $\mathrm{CO}_{2}$ released by the ninhydrin reaction as described by Read et al. (1984) and $\mathrm{CO}_{2}$ was analysed by gas chromatography (Roboprep G; Europa Scientific, Crewe, Ches.) coupling with isotope ratio mass spectrometry (VG Isogas; Middlewich, Ches.). Threonine enrichments were determined, after t-butyldimethylsilyl derivatization (with $N$-methyl- $N$ t-butyldimethyl trifluoroacetamide), by gas chromatography-mass spectrometry (Nermag R10-10C; Delsi-Nermag, Argenteuil, France) as previously described (Ballèvre et al. $1991 b$ ). Glycine and threonine enrichments were expressed in atom percent excess (APE), corresponding to the enrichment of the sample minus basal isotope abundance measured before starting the infusion.

\section{L-Threonine 3-dehydrogenase activity measurement}

TDG specific activity was assayed according to the technique described by Le Floc'h $e t$ al. (1994). TDG activity was measured as the rate of aminoacetone formation in the liver and in the pancreas. A standard assay was performed with newly synthesized aminoacetone (Gabriel \& Colman, 1902).

\section{Calculations}

Enrichments and specific radioactivity of glycine in the secondary pool reached plateau after $8 \mathrm{~h}$ of infusion. Consequently, kinetic calculations were made with mean values of threonine and glycine enrichments and glycine specific radioactivities during the last $2 \mathrm{~h}$ of infusion. Threonine and glycine flux rates, and threonine to glycine disposal rate were calculated using equations adapted from Ballèvre et al. (1991 b). All calculations were made with plasma values of enrichment and specific radioactivity.

The fractional contribution of threonine to glycine production $\left(\mathrm{FC}_{\mathrm{Thr}-\mathrm{Gly}}\right)$ was measured 
from secondary pool enrichment:primary pool enrichment ratio during $L-\left[1-{ }^{13} \mathrm{C}\right]$ threonine infusion:

$$
\mathrm{FC}_{\mathrm{Thr}-\mathrm{Gly}}=100 \times\left(\mathrm{E}_{\mathrm{Gly}} / \mathrm{E}_{\mathrm{Thr}}\right) \text {, }
$$

where $E_{G l y}$ and $E_{T h r}$ are plasma enrichments of glycine and threonine.

The glycine production rate $\left(\mathrm{P}_{\mathrm{Gly}}\right)$ could be calculated during the infusion of $\left[1-{ }^{14} \mathrm{C}\right]-$ glycine or $\left[2-{ }^{3} \mathrm{H}\right]$ glycine:

$$
\mathrm{P}_{\mathrm{Gly}}=\mathrm{i}_{\mathrm{Gly}} / \mathrm{SR}_{\mathrm{Gly}} \text {, }
$$

where $i_{\text {Gly }}$ is the infusion rate and $\mathbf{S R}_{\mathrm{Gly}}$ is the plasma glycine specific radioactivity.

The rate of threonine disposal into glycine $\left(\mathrm{DR}_{\mathrm{Thr}-\mathrm{Gly}}\right)$ was calculated by multiplying $\mathrm{FC}_{\mathrm{Thr}-\mathrm{Gly}}$ by the production rate of glycine in the secondary pool.

\section{Statistical analysis}

Data were submitted to ANOVA using the general linear models procedure of Statistical Analysis Systems (1989). The effect of diet was tested against the residual variation between animals. The effects of tissue and tissue $\times$ diet interaction on the enrichments of threonine and glycine were tested against the residual variation within animals as recommended for a split-plot design (Cochran \& Cox, 1957). When statistical difference was established by the Fisher-Snedecor test $(P<0.1$ for the null hypothesis), means were compared by Student's $t$ test and differences were declared significant at $P<0.05$.

\section{RESULTS}

\section{Growth and nitrogen balance}

$\mathrm{N}$ retention (Table 2), calculated as the difference between $\mathrm{N}$ intake and $\mathrm{N}$ excreted (urine and faeces), was not significantly $(P=0 \cdot 3)$ affected by the level of threonine supply, but tended to be lower in pigs fed on the LT diet than in the C and the HT groups. Threonine retention was calculated from $\mathbf{N}$ retention assuming that threonine composition of body protein was constant $(3.9 \mathrm{~g} / 16 \mathrm{~g} \mathrm{~N}$ according to Campbell \& Taverner, 1988). Consequently, the response of threonine retention was parallel to the response of $\mathbf{N}$ retention.

\section{Tracer kinetics}

Plateau values of enrichment are reported in Table 3. Plasma and pancreas threonine enrichments decreased when the level of dietary threonine increased, but pancreas threonine enrichment was not significantly lower in the HT groups than in pigs fed on the $\mathrm{C}$ diet. Liver threonine enrichment was not affected by threonine supply. Comparison of threonine enrichment between plasma, liver and pancreas showed a highly significant interaction $(P=0.0006)$ : plasma and pancreas threonine enrichments were reduced when threonine intake increased whereas liver threonine enrichment remained unchanged. Threonine enrichment was significantly higher in the plasma than in the pancreas in pigs fed on the LT diet, but the difference between plasma and pancreas was not significant in the other two groups. The increase in dietary threonine addition led to a significant increase in plasma, liver, HA and pancreas glycine enrichments between the LT group and the $\mathrm{C}$ group, whereas there was no significant difference between the $\mathrm{C}$ and the HT groups. Glycine pancreas enrichment was higher than plasma and liver enrichment, but in pigs fed on the LT diet the difference was not significant.

Glycine fluxes calculated either from plasma $\left[1-{ }^{14} \mathrm{C}\right]$ glycine or $\left[2-{ }^{3} \mathrm{H}\right] \mathrm{glycine}$ specific radioactivities were not significantly different (Table 4).

The fractional contribution of threonine to glycine $\left(\mathrm{FC}_{\mathrm{Thr}-\mathrm{Gly}}\right)$ showed no significant difference between the $\mathrm{C}$ and the HT groups (Table 5), but $\mathrm{FC}_{\mathrm{Thr}-\mathrm{Gly}}$ was reduced by 77 and 
Table 2. Threonine intake and retention, nitrogen retention and digestibility of growing pigs fed on a threonine-deficient diet $(L T)$, a control diet $(C)$ or a diet with an excess of threonine $(H T)^{*}$

(Mean values for four pigs per dietary group, with their pooled standard error calculated from the error mean square)

\begin{tabular}{|c|c|c|c|c|c|}
\hline Diets... & LT & C & HT & SEM & $P \dagger$ \\
\hline $\begin{array}{l}\text { Weight at infusion }(\mathrm{kg}) \\
\text { Threonine intake }(\mathrm{g} / \mathrm{d}) \\
\text { N retention }(\mathrm{g} / \mathrm{d}) \\
\text { Threonine retention }(\mathrm{g} / \mathrm{d}) \\
\text { AND }(\mathrm{g} / \mathrm{kg})\end{array}$ & $\begin{array}{l}29 \cdot 8 \\
5 \cdot 62^{\mathrm{c}} \\
6 \cdot 6 \\
1 \cdot 59 \\
598\end{array}$ & $\begin{array}{c}29 \cdot 4 \\
6 \cdot 89^{b} \\
9 \cdot 7 \\
2 \cdot 34 \\
687\end{array}$ & $\begin{array}{l}30 \cdot 7 \\
8 \cdot 83^{\mathrm{a}} \\
10 \\
2 \cdot 41 \\
603\end{array}$ & $\begin{array}{c}0.85 \\
0.18 \\
1.59 \\
0.38 \\
53.7\end{array}$ & $\begin{array}{l}0.56 \\
0.0001 \\
0.30 \\
0.30 \\
0.45\end{array}$ \\
\hline
\end{tabular}

AND, apparent $\mathbf{N}$ digestibility.

$\mathbf{a}, \mathbf{b}, \mathbf{c}$ Mean values within a row with unlike superscript letters were significantly different $(P<0.05$, Student's $t$ test).

* For details of diets and procedures, see Table 1 and pp. 826-828.

$\uparrow$ Probability under null difference hypothesis according to Snedecor-Fisher test between diets.

Table 3. Plateau values* (atom percent excess) of threonine and glycine enrichments during $10 \mathrm{~h}$ infusion of $L-\left[1-{ }^{13} \mathrm{C}\right]$ threonine in pigs fed on a low-threonine diet $(L T)$, a control diet $(C)$ or a high-threonine diet $(H T) \dagger$

(Mean values for four pigs per dietary treatment with their pooled standard error calculated from the error mean square)

\begin{tabular}{|c|c|c|c|c|c|}
\hline Diets... & $\mathbf{L T}$ & C & HT & SEM & $P \ddagger$ \\
\hline \multicolumn{6}{|l|}{ Threonine } \\
\hline Plasma & $7 \cdot 40^{\mathrm{a}, \mathrm{x}}$ & $5 \cdot 57^{b, x}$ & $4 \cdot 47^{c}$ & 0.32 & 0.004 \\
\hline Liver & $3 \cdot 38^{2}$ & $3.39^{y}$ & 3.97 & 0.39 & $0 \cdot 50$ \\
\hline Pancreas & $6.48^{\mathrm{a}, \mathrm{y}}$ & $5 \cdot 12^{\mathrm{b}, \mathrm{x}}$ & $4 \cdot 58^{\mathrm{b}}$ & 0.28 & 0.003 \\
\hline \multicolumn{6}{|l|}{ Glycine§ } \\
\hline Plasma & $0.022^{\mathrm{b}}$ & $0.068^{a}$ & $0.068^{\mathrm{a}}$ & 0.011 & 0.031 \\
\hline Liver & $0.016^{\mathrm{b}}$ & $0.060^{a}$ & $0.071^{\mathrm{a}}$ & 0.005 & 0.0001 \\
\hline Urine & $0.013^{b}$ & $0.062^{\mathrm{a}}$ & $0.067^{\mathrm{a}}$ & 0.009 & 0.004 \\
\hline Pancreas & $0.067^{\mathrm{b}}$ & $0.57^{3}$ & $0.75^{\mathrm{a}}$ & 0.11 & 0.0052 \\
\hline
\end{tabular}

a,b,c Mean values within a row with unlike superscript letters were significantly different $(P<0.05)$.

x,y,z Mean values within a column with unlike superscript letters were significantly different $(P<0.05)$.

* For plasma, plateau values were calculated from the measurements made during the last $2 \mathrm{~h}$ of infusion.

$\dagger$ For details of diets and procedures, see Table 1 and pp. 826-829.

$\$$ Probability under the null difference hypothesis according to the Snedecor-Fisher test between diets.

$\$$ The diet $\times$ tissue interaction was significant for threonine enrichment $(P=0.0006)$. Because of the higher glycine enrichment $\left(E_{G l y}\right)$ values in pancreas than in plasma and liver, pancreas variance was also higher. Therefore, the pancreas was not included in the tissue $\times$ diet interaction statistical analysis of $\mathrm{E}_{\mathrm{Gly}}$. In this case, tissue $\times$ diet interaction was not significant for $\mathrm{E}_{\mathrm{Gly}}$.

$80 \%$ in pigs fed on the LT diet compared with the C and HT groups respectively. When glycine flux was calculated from $\left[1-{ }^{14} \mathrm{C}\right]$ glycine specific radioactivity, the variations of threonine oxidation rate to glycine were the same as those of $\mathrm{FC}_{\mathrm{Thr}-\mathrm{aly}}$. Liver TDG specific activity was significantly lower in pigs fed on the LT diet compared with pigs fed on the C diet $(P=0.025)$, but pancreas TDG specific activity was not different between the three experimental groups. Plasma threonine flux was significantly reduced according to the decrease in dietary threonine $(P=0.0001)$. 
Table 4. Glycine flux* (umol/kg per h), in pigs fed on a low-threonine diet (LT), a control diet (C) or a high-threonine diet $(H T)$, estimated from $\left[1-{ }^{14} \mathrm{C}\right] \mathrm{glycine}$ and $\left[2-{ }^{3} \mathrm{H}\right] \mathrm{glycine}$ infusion $\dagger$

(Mean values with their standard errors for four pigs per dietary group)

\begin{tabular}{|c|c|c|c|c|c|}
\hline & \multicolumn{2}{|c|}{$\left[1-{ }^{14} \mathrm{C}\right]$ glycine } & \multicolumn{2}{|c|}{$\left[2-{ }^{3} \mathrm{H}\right]$ glycine } & \multirow[b]{2}{*}{$P \ddagger$} \\
\hline & Mean & SE & Mean & SE & \\
\hline $\begin{array}{l}\text { LT } \\
\text { C } \\
\text { HT }\end{array}$ & $\begin{array}{l}869 \\
724 \\
677\end{array}$ & $\begin{array}{l}74 \\
38 \\
33\end{array}$ & $\begin{array}{l}776 \\
723 \\
688\end{array}$ & $\begin{array}{l}66 \\
30 \\
63\end{array}$ & $\begin{array}{l}0.13 \\
0.98 \\
0.85\end{array}$ \\
\hline Effect of diet $(P=)$ & \multicolumn{2}{|c|}{0.06} & \multicolumn{2}{|c|}{0.15} & \\
\hline
\end{tabular}

* Glycine flux was calculated from plasma glycine specific radioactivity at plateau after correction of [2- $\left.{ }^{3} \mathrm{H}\right]$ glycine specific radioactivity for the loss of $26.5 \%$ of tracer (for details see p. 832).

$\dagger$ For details of diets, see Table 1.

\# Effect of tracer: probability under null difference hypothesis for Snedecor-Fisher test.

Table 5. Fractional contribution of threonine to glycine flux $\left(F C_{\text {Thr-Gly }}\right)$, threonine oxidation rate to glycine $\left(D R_{T h r-G l y}\right)$ and plasma threonine flux $\left(P R_{T h r}\right)$ estimated from $10 \mathrm{~h}$ infusion of $L-\left[1-{ }^{13} \mathrm{C}\right]$ threonine and $\left[1-{ }^{14} \mathrm{C}\right]$ glycine, in growing pigs fed on a low-threonine-diet $(L T), a$ control diet $(C)$ or a high-threonine diet $(H T)^{* \dagger}$

(Mean values for four pigs per dietary treatment, with their pooled standard error calculated from the error mean square)

\begin{tabular}{|c|c|c|c|c|c|c|}
\hline \multirow[b]{2}{*}{ Diets } & \multirow{2}{*}{$\underset{(\%)}{F C_{\text {Thr-Gly }}}$} & \multirow{2}{*}{$\begin{array}{c}\text { DR }_{\text {Thr-Gly }} \\
(\mu \mathrm{mol} / \mathbf{k g} \text { per } \mathrm{h})\end{array}$} & \multirow{2}{*}{$\begin{array}{c}\text { PR }_{\text {Thr }} \\
(\mu \mathrm{mol} / \mathrm{kg} \text { per } \mathrm{h})\end{array}$} & \multicolumn{2}{|c|}{$\mathrm{TDG}_{\ddagger}^{+}$} & \multirow{2}{*}{$\begin{array}{c}\text { Plasma threonine } \\
(\mathrm{nmol} / \mathrm{ml})\end{array}$} \\
\hline & & & & Liver & Pancreas & \\
\hline LT & $0 \cdot 29^{b}$ & $2.43^{\mathrm{b}}$ & $\overline{161^{c}}$ & $2 \cdot 10^{b}$ & 1 & 95 \\
\hline $\mathrm{C}$ & $1-25^{\mathrm{a}}$ & $9 \cdot 13^{2}$ & $215^{\mathrm{b}}$ & $3.75^{\mathrm{a}}$ & $3 \cdot 1$ & 257 \\
\hline HT & $1 \cdot 51^{\mathrm{a}}$ & $10 \cdot 45^{\mathrm{a}}$ & $268^{\mathrm{a}}$ & $3 \cdot 2^{8 b}$ & $2 \cdot 9$ & 428 \\
\hline SEM & 0.21 & 1.85 & 0.43 & 0.87 & 1.9 & 43 \\
\hline$P \S$ & 0.012 & 0.028 & 0.0001 & 0.06 & 0.28 & 0.0001 \\
\hline
\end{tabular}

TDG, L-threonine 3-dehydrogenase (EC 1.1.1.103).

a,b.c Mean values within a column not sharing a common superscript letter were significantly different $(P<0.05$, Student's $t$ test $)$.

* $F C_{\text {Thr-Gly }}$ and PR Thr were calculated from plasma values of enrichments during L- $\left[1-{ }^{13} \mathrm{C}\right]$ threonine infusion.

DR $R_{\text {Thr-Gly }}$ was calculated as $\mathrm{FC}_{\mathrm{Thr}-\mathrm{Gly}} \times$ glycine flux.

$\dagger$ For details of diets, see Table 1 .

$\$$ TDG activity is expressed as the rate of aminoacetone formation ( $\mu \mathrm{mol} / \mathrm{min}$ per $\mathrm{g}$ tissue).

$\S$ Probability under the null difference hypothesis for the Snedecor-Fisher test between diets.

\section{DISCUSSION}

Estimation of whole-body glycine flux

The multitracer model developed and validated by Ballèvre et al. $(1990,1991 a)$ in pigs allows the calculation of threonine oxidation through the two degradative pathways, TDG and TDH. Thus, it was shown that more than $80 \%$ of threonine oxidation occurred through glycine production in the liver. However, we have previously shown that, when dietary threonine supply is not in excess of the requirement, threonine oxidation through the TDG pathway probably occurs mainly in extrahepatic tissues as suggested by the significantly higher glycine enrichment in the plasma than in the liver during the infusion of $L-\left[1-{ }^{13}\right.$ C $]$ threonine (Le Floc'h et al. 1995). That is why we have calculated total threonine 
oxidation to glycine from the plasma values of glycine and threonine enrichment and from the plasma glycine flux, as an estimate for whole-body glycine flux. Unfortunately, glycine flux calculated from glycine portal infusion did not correspond to the whole-body plasma glycine flux because $\left[1{ }^{-14} \mathrm{C}\right]$ glycine avoided extraction by the gut before the sampling site. Moreover, following portal infusion a substantial amount of tracer would not appear in the systemic plasma because of the 'first-pass' removal by the liver. Therefore, in order to calculate whole-body plasma glycine flux, $\left[2-{ }^{3} \mathrm{H}\right]$ glycine, also, was infused through the jugular vein. Specific radioactivity of $\left[2-{ }^{3} \mathrm{H}\right]$ glycine measured from systemic plasma allowed the estimation of whole-body plasma flux because plasma was sampled upstream from the infusion site (Katz et al. 1981).

Glycine and serine are precursors for each other (Christensen et al. 1986) and the synthesis of serine from glycine involves the loss of one $\mathrm{H}$ on $\mathrm{C} 2$. Consequently, the loss of $\left[2-{ }^{3} \mathrm{H}\right] \mathrm{glycine}$ label during the jugular infusion of this tracer led to an overestimation of the calculated glycine flux. The loss of label of $\left[2-{ }^{3} \mathrm{H}\right] \mathrm{glycine}$ was evaluated in a preliminary experiment during the constant infusion of both $\left[2{ }^{3} \mathrm{H}\right]$ glycine and $\left[1-{ }^{14} \mathrm{C}\right] \mathrm{glycine}$ in the jugular vein with plasma sampling $50 \mathrm{~mm}$ upstream from the infusion site. In these conditions the two tracers should have yielded the same value of plasma glycine flux. Thus, it was possible to correct the value of $\left[2-{ }^{3} \mathrm{H}\right]$ glycine specific radioactivity measured in the plasma. Of the six pigs used in this experiment, three were fed on the LT diet and three were fed on the HT diet. No difference appeared between diets; the mean estimated loss of tracer was 26.5 (SE 2.1) \%. We concluded that the loss of label during the constant infusion of [2${ }^{3} \mathrm{H}$ ]glycine through the cranial vena cava was fairly constant whatever the level of threonine supply. In the main experiment, since $\left[1-{ }^{14} \mathrm{C}\right]$ glycine was infused into the portal vein and [2${ }^{3} \mathrm{H}$ ]glycine was infused in the cranial vena cava, the two measurements of glycine flux should have been different even when $\left[2-{ }^{3} \mathrm{H}\right]$ glycine specific radioactivity was corrected, but they gave similar values. This may be explained on the one hand by the first-pass extraction by the liver of a part of the tracer which did not appear in the systemic plasma and which led to the overestimation of plasma glycine flux estimated from vena cava plasma [1$\left.{ }^{14} \mathrm{C}\right]$ glycine specific radioactivity. On the other hand, since $\left[1-{ }^{14} \mathrm{C}\right]$ glycine was sampled from the vena cava and since dilution by the gut was missed, this led to an underestimation of glycine flux. Consequently, these two factors (extraction by the liver and lack of dilution and extraction by the gut) which act in an opposite way on the estimate of glycine flux values from $\left[1-{ }^{14} \mathrm{C}\right]$ glycine specific radioactivity have contributed to equalize flux values calculated from the two tracers infused in different sites. Finally, because it was a direct measurement, $\left[1-{ }^{14} \mathrm{C}\right] \mathrm{glycine}$ specific radioactivity was considered to be a more reliable estimate for each individual value than corrected $\left[2{ }^{3} \mathrm{H}\right]$ glycine specific radioactivity and was used to calculate plasma glycine flux.

\section{Rate of threonine entry into the liver and its consequences on threonine oxidation into glycine}

In the present study, although the trend of a higher value in the liver was clear at low dietary threonine supply, we failed to find any significant difference between plasma and liver glycine enrichment as we had previously shown (Le Floc'h et al. 1995). Indeed, liver threonine oxidation would have implied a lower glycine enrichment in the plasma than in the liver because of the further dilution in the systemic plasma of labelled glycine produced in the liver from labelled threonine as discussed earlier. But the variations of the liver:plasma glycine enrichment ratio may reflect all intermediate situations between a totally hepatic and a totally extrahepatic oxidation process; the most important is the contribution of the liver to total threonine oxidation. Consequently, the lack of significant difference between liver and plasma glycine enrichment did not allow us to conclude that 
(a)
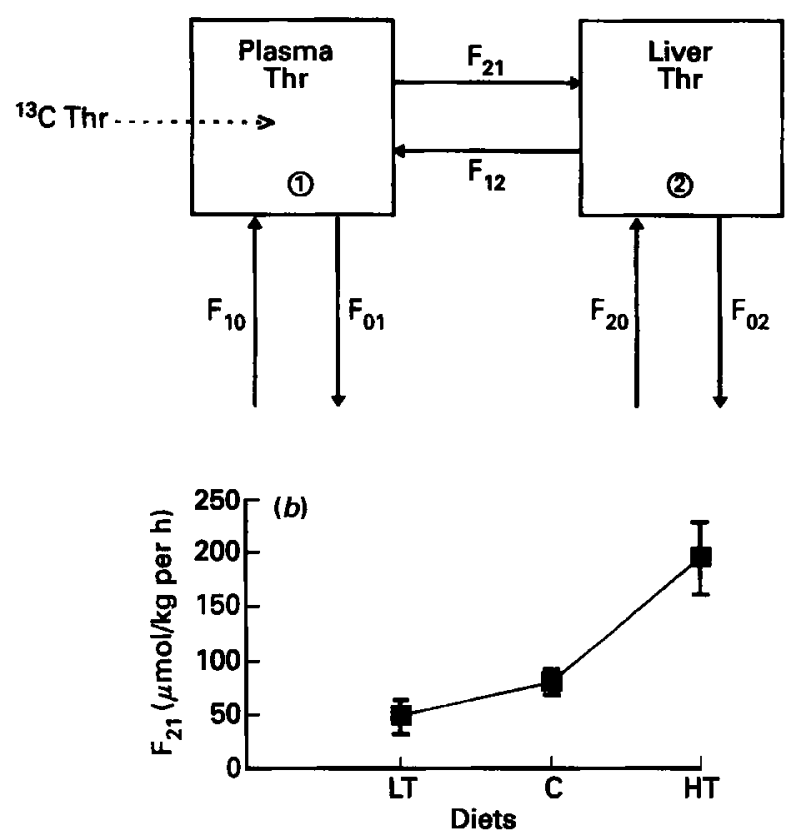

Fig. 1(a) Model used to calculate threonine exchange between plasma (compartment 1) and liver (compartment 2). $F_{21}$ represents the rate of threonine entry into the liver and $F_{12}$ represents the rate of threonine transport from the liver to the plasma. Threonine transport into the liver $\left(\mathrm{F}_{21}\right)$ was calculated according to the two-pool reversible model described by Shipley \& Clark (1972): $\mathrm{F}_{21}=\mathrm{F}_{20} \times \mathrm{P} /(1-\mathrm{P})$ where $\mathrm{F}_{20}$ is the rate of threonine release from liver protein breakdown and $P$ is the liver threonine enrichment:plasma threonine enrichment ratio. $(b) F_{21}$ is calculated with experimental values of $P$ for the three groups of pigs (low-threonine diet (LT), control diet (C) and high-threonine diet $(\mathrm{HT})$ ) assuming that $\mathrm{F}_{20}$ was constant according to dietary threonine supply $(50 \mu \mathrm{mol} / \mathrm{kg}$ per h). According to this calculation, threonine entry rate into the liver was significantly higher $(P=0.0012)$ in the HT group than in the $\mathrm{C}$ group. The difference between the $\mathrm{C}$ and $\mathrm{LT}$ groups was not significant.

the contribution of the extrahepatic tissues to threonine oxidation was minor, especially when dietary threonine supply was low.

The comparison of plasma and liver threonine enrichment revealed a significant interaction. When plasma threonine enrichment was reduced according to the level of threonine intake, liver enrichment remained unchanged. One question arises about the reasons why the enrichment of liver threonine was not affected by the dilution of plasma labelled threonine. The value of threonine enrichment measured in the liver may result either from the rate of threonine entry from the systemic plasma or from the rate of threonine release from liver protein breakdown. This can be demonstrated easily with the model described in Fig. 1(a). Threonine transport in the liver $\left(F_{21}\right)$ was calculated according to the two-pool reversible model described by Shipley \& Clark (1972) as follows:

$$
F_{21}=F_{20} \times P /(1-P) \text {, }
$$

where $F_{20}$ is the rate of threonine release from protein breakdown and $P$ is the liver threonine enrichment:plasma threonine enrichment ratio. The main simplification of this model was to assume that the plasma is an homogeneous pool. In fed pigs the liver receives a large amount of threonine from the portal vein and $F_{21}$ should be calculated from portal plasma threonine enrichment rather than from systemic plasma enrichment. Nevertheless, portal and systemic plasma threonine enrichment should vary in the same way with dietary threonine supply and systemic plasma enrichment can be used to estimate the variation of 
$F_{21}$. If $F_{20}$ was constant, the variation of threonine entry in the liver would be that of the ratio $P /(1-P)$. When this calculation was made from plasma and liver threonine enrichments measured in the three experimental groups, it was clear that threonine entry in the liver was fairly constant at low and adequate threonine supply and increased sharply with excess supply (Fig. 1(b)), as was suggested by Bloxam (1975). According to this hypothesis, we can explain the interaction between plasma and liver threonine enrichment. If we assumed that liver threonine turnover rate was constant, a large amount of poorly enriched threonine would enter the liver from the systemic plasma in pigs fed on the HT diet and the liver threonine pool would tend to equilibrate with the plasma threonine pool at low enrichment. By contrast, in pigs fed on the LT diet, threonine entry from the plasma would be low and this might prevent a parallel rise of threonine enrichment in the plasma and in the liver threonine pool.

The high value of $K_{\mathrm{m}}$ reported for TDG from pig liver mitochondria (Tressel et al. 1986) implies that liver threonine oxidation should depend on the availability of threonine at the oxidation site and, consequently, on the rate of entry of threonine from the extracelluar to the intracellular pool. In rats, Bloxam (1975) has shown that the transport of threonine into the liver is the limiting step for threonine degradation in the liver, and this might have contributed to sparing threonine for protein synthesis in the peripheral tissues. Moreover, in growing pigs, dietary threonine seems to be poorly taken up by the liver compared with the other essential amino acids except branched-chain amino acids (Rérat et al. 1992). These results are strongly supported by our estimation of threonine transport in the liver and the comparison of plasma and liver glycine enrichments according to the dietary threonine supply. In pigs fed on the HT diet the contribution of the liver to total oxidation would be more important than in the LT group since threonine entered and was oxidized in the liver.

According to previous results (Le Floc'h et al. 1995) the pancreas should be the main extrahepatic tissue involved in threonine catabolism through the TDG pathway. High TDG specific activity had already been measured in the pancreas of chicken and rat (Davis \& Austic, 1982, 1994) and in the pancreas of pig (Le Floc'h, unpublished results). The present findings agreed with these results and showed that labelling of glycine from threonine was three- to elevenfold higher in the pancreas than in the plasma. This result implies that the pancreas may be a major site of de novo glycine synthesis from threonine. However, since glycine flux could not be determined in the pancreas, it was not possible to estimate the contribution of this tissue to total threonine oxidation.

\section{Threonine kinetics and oxidation}

The rise in plasma threonine flux associated with the increase in threonine intake has already been shown in humans (Zhao et al. 1986). In the present pigs the increase in plasma threonine flux was three times the increase in threonine intake. This result would imply an acceleration of protein turnover parallel to the increase in threonine oxidation. Alternatively, the increase in plasma threonine flux between the control and the highthreonine group may be a consequence of the accumulation of plasma unlabelled threonine which will exaggerate the dilution of labelled threonine resulting from an acceleration of whole-body flux. This accumulation is commonly observed as soon as threonine supply is in excess of the requirement (Rosell \& Zimmerman, 1984). Our results showed that plasma glycine and plasma threonine flux varied in opposite directions. This means that glycine flux was higher in the LT group than in the other two groups. Because glycine is a nonessential amino acid, glycine flux can be altered by de novo glycine synthesis which might be more important in pigs fed on the LT diet. If an increase in de novo glycine synthesis really occurred in pigs fed on the LT diet, the precursor was most probably not threonine, 


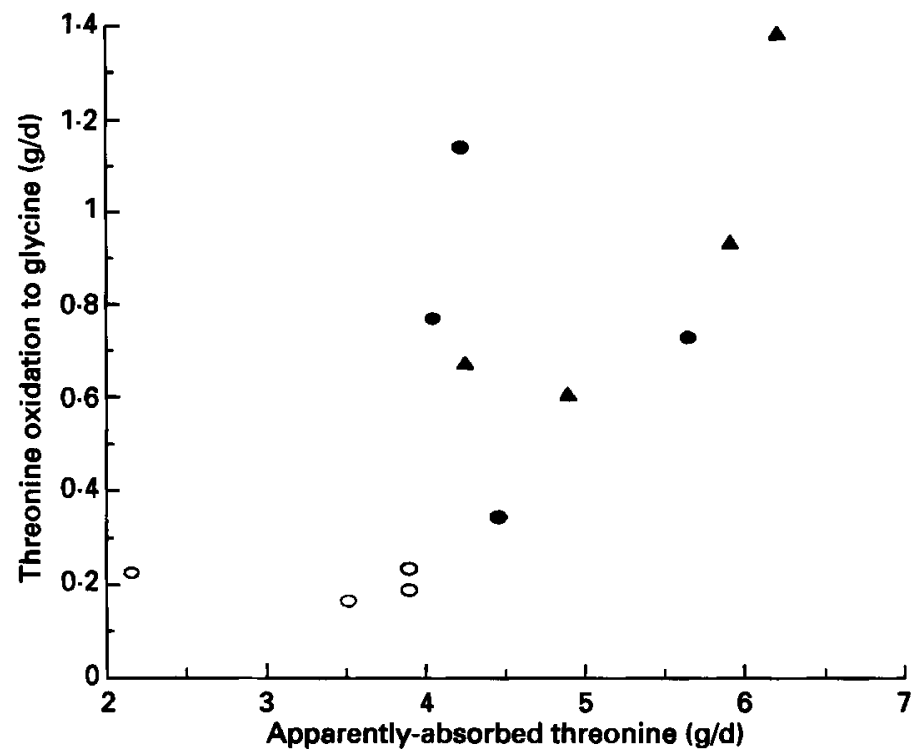

Fig. 2. Effect of apparently absorbed threonine on in vivo threonine oxidation to glycine in growing pigs fed on a low-threonine diet (LT) (O), a control diet (C) (๑) or a diet with an excess of threonine (HT) (A). Each point represents the individual value of threonine oxidation calculated from plasma data of threonine and glycine enrichments and from $\left[1-{ }^{14} \mathrm{C}\right]$ glycine specific radioactivity. Apparently-absorbed threonine was estimated from the value of threonine intake and the nitrogen apparent digestibility measured for each pig.

but there is no obvious explanation for this from the literature. More specific studies are needed to further our understanding of the regulation of de novo glycine synthesis.

The lack of significant response of threonine oxidation between the $\mathrm{C}$ and the HT groups could be explained by the results of $\mathrm{N}$ balance. The analysis of individual values of the four pigs fed on the HT diet showed that two pigs presented a low rate of threonine oxidation. For these two animals, apparent $\mathbf{N}$ digestibility (AND) was quite low compared with that of the other two animals (50 v. $70 \%$ respectively). Consequently, these pigs had probably digested less $\mathrm{N}$ than was expected. The digestibility of added free threonine in the HT diet may be assumed to be $100 \%$, but free threonine represented only $40 \%$ of total dietary threonine, the remaining $60 \%$ was provided by the protein of the feedstuffs. Assuming proportionality to the total apparently digestible $\mathrm{N}$, an estimate of absorbed threonine was calculated by adding feedstuff-derived threonine multiplied by AND to supplemental threonine. When individual results of oxidation were plotted against this estimate of absorbed threonine (Fig. 2), the response of threonine oxidation to glycine showed that oxidation seemed to be low and constant until absorbed threonine approached $4 \mathrm{~g} / \mathrm{d}$. Then, above this value, threonine oxidation rose sharply. A similar response of threonine oxidation to threonine intake was previously reported for rats (Kang-Lee \& Harper, 1978) and for humans (Zhao et al. 1986).

About $40 \%$ of threonine in the HT diet was added in a free form. Therefore, regardless of protein digestibility, the relative excess of digestible threonine compared with the other amino acids was maintained in all pigs in this group. Thus, threonine was still favoured in the competition with the other amino acids for transport into the liver and this may explain why a high rate of threonine entry into the liver was calculated, even in the two pigs displaying low digestibility values. Moreover, these two pigs had much lower liver TDG specific activities than the other two pigs fed on the same diet. This was probably the consequence of the low amount of digested protein. Indeed, in a previous experiment, we 
showed in fattening pigs that liver TDG specific activity was induced by protein addition (Le Floc'h et al. 1994), and both TDG specific activity measured in vitro and the rate of threonine oxidation measured in vivo were depressed in pigs fed on a protein-deficient diet (Ballèvre et al. 1991 a). The induction of TDG specific activity by excess dietary protein has been observed previously in the chicken (Aoyama \& Motokawa, 1981). Consequently, in those two pigs where threonine oxidation remained low we may assume that enzyme specific activity could not be induced. This hypothesis is supported by the findings of KangLee \& Harper (1978) who showed in rats that in vivo threonine oxidation increased parallel to dietary threonine intake only when enzyme specific activity had been previously induced by an excess of protein.

Threonine retention estimated from tracer infusion was higher than values estimated from $\mathrm{N}$ balance $(2 \cdot 4 v$. $5 \cdot 6 \mathrm{~g} / \mathrm{d})$. One of the reasons for this discrepancy was the underestimation of threonine oxidation to glycine calculated from plasma data whilst threonine oxidation into glycine occurred in tissues. An accurate estimate of threonine oxidation to glycine will be made when we can measure, separately, glycine flux in the liver and in the pancreas. Moreover, we have no estimate of the rate of threonine oxidation into ketobutyrate, the second degradative pathway of threonine. However, we previously showed that the contributions of the TDH pathway to total threonine oxidation were 23 and $13 \%$ for the threonine-deficient diet and the control diet respectively (Le Floc'h et al. 1995). Thus, the lack of a value for threonine oxidation to ketobutyrate cannot entirely explain the difference between the two estimates of total threonine oxidation.

Most of the enzymes of amino acid catabolism are not induced by their substrate. However, in the present pigs we found an effect of dietary threonine level on liver and pancreas TDG specific activity (LT group $v$. C group). These results agree with previous findings in fattening pigs (Le Floc'h et al. 1994) and in growing pigs where only pancreas TDG specific activity was induced by threonine (Le Floc'h et al. 1995). Since TDG specific activity measured in the HT group was not significantly altered in spite of the excess dietary threonine, it was not possible to conclude that TDG was induced by threonine. Indeed, the lower TDG specific activity measured in the liver and the pancreas of pigs fed on the LT diet compared with pigs fed on the $\mathrm{C}$ diet might have been the consequence of a lower TDG enzyme net synthesis, to the same extent as lower whole-body protein net synthesis as a result of the amino acid imbalance due to threonine deficiency.

The present study confirms that threonine oxidation through the TDG pathway takes place both in the liver and in extrahepatic tissues. Accordingly, our results provide additional support to the hypothesis that threonine transport in the liver could be the limiting step of threonine oxidation in this tissue when dietary threonine supply is low or adequate. The pancreas was probably the main extrahepatic tissue involved in threonine catabolism to glycine. The variation of threonine oxidation according to an estimate of threonine absorbed was biphasic. Indeed, threonine oxidation calculated from plasma data remained low and constant for low threonine intake and increased greatly for higher threonine intake.

We are grateful to Sylviane Daniel, Nadine Mézière, Y. Colléaux and P. Ganier for laboratory technical assistance. We also thank Y. Lebreton and F. Legouevec for surgical preparation of the pigs and animal care. Special acknowledgements are addressed to J. Prugnaud for his help in mass spectrometry analysis.

\section{REFERENCES}

Aoyama, Y. \& Motokawa, Y. (1981). L-threonine dehydrogenase of chicken liver: purification, characterization and physiological significance. Journal of Biological Chemistry 256, 12367-12373. 
Baker, D. H. \& Chung, T. K. (1992). Ideal protein for swine and poultry. Kyowa Hakko Technical Review 4.

Ballèvre, O., Cadenhead, A., Calder, A. G., Rees, W. D., Lobley, G. E., Fuller, M. F. \& Garlick, P. J. (1990). Quantitative partition of threonine oxidation in pigs: effect of dietary threonine. American Journal of Physiology 261, E483-E491.

Ballèvre, O., Houlier, M. L., Prugnaud, J., Bayle, G., Bercovici, D., Sève, B. \& Arnal, M. (1991a). Altered partition of threonine metabolism in pigs by protein-free feeding or starvation. American Journal of Physiology 261, E748-E757.

Ballèvre, O., Prugnaud, J., Houlier, M. L. \& Arnal, M. (1991 b). Assessment of threonine metabolism in vivo by gas chromatography/mass spectrometry and stable isotope infusion. Analytical Biochemistry 193, $212-219$.

Bird, M. I., Nunn, P. B. \& Lord, L. A. J. (1984). Formation of glycine and aminoacetone from L-threonine by rat liver mitochondria. Biochimica et Biophysica Acta 802, 229-236.

Bloxam, D. L. (1975). Restriction of hepatic gluconeogenesis and ureogenesis from threonine when at low concentrations. American Journal of Physiology 229, 1718-1723.

Campbell, R. G. \& Taverner, M. R. (1988). The tissue and dietary protein and amino acid requirements of pigs from 8.0 to $20.0 \mathrm{~kg}$ live weight. Animal Production 46, 283-290.

Chavez, E. R. \& Bayley, H. S. (1976). Amino acid metabolism in the piglet. 2. Influence of fasting on plasma free amino acid concentration and in vivo oxidation of methionine, isoleucine and threonine. British Journal of Nutrition 36, 189-198.

Christensen, H. N., Curthoys, N. P., Mortimore, G. E., Smith, R. J., Goldstein, L. \& Harper, A. E. (1986). Interorgan transport. Federation Proceedings 45, 2165-2183.

Cochran, W. G. \& Cox, G. M. (1957). Experimental Designs. New York: Wiley.

Dale, R. A. (1978). Catabolism of threonine in mammals by coupling of L-threonine-3-dehydrogenase with 2amino-3-oxobutyrate-CoA ligase. Biochimica et Biophysica Acta 544, 496-503

Davis, A. T. \& Austic, R. E. (1982). threonine-degrading enzymes in the chicken. Poultry Science 61, $2107-2111$.

Davis, A. T. \& Austic, R. E. (1994). Dietary threonine imbalance alters threonine dehydrogenase activity in isolated hepatic mitochondria of chicks and rats. Journal of Nutrition 124, 1667-1677.

Egan, A. R., MacRae, J. C. \& Lamb, C. S. (1983). Threonine metabolism in sheep 1. The catabolism and gluconeogenesis in mature blackface wethers given poor quality hill herbage. Journal of Nutrition 49, 373-383.

Freedland, R. A. \& Avery, E. H. (1964). Studies on threonine and serine dehydrase. Journal of Biological Chemistry 239, 3357-3360.

Fuller, M. F., Wang, W. T. C. \& Giles, L. R. (1989). The optimum dietary amino acid pattern for growing pigs. 2. Requirements for maintenance and for tissue protein accretion. British Journal of Nutrition 62, $255-267$.

Gabriel, S. \& Colman, J. (1902). Zur kenntniss des amidoacetones (Knowledge of aminoacetone). Berichte der Deutschen Chemishen Gesellschast 35, 3805-3811.

Kang-Lee, Y. A. E. \& Harper, A. E. (1978). Threonine metabolism in vivo: effect of threonine intake and prior induction of threonine dehydratase in rats. Journal of Nutrition 108, 163-175.

Katz, J., Okajima, F., Chenoweth, M. \& Dunn, A. (1981). The determination of lactate turnover in vivo with 14 C labelled lactate: the significance of sites of tracer administration and sampling. Biochemical Journal 194, 513-524.

Le Floc'h, N., Sève, B. \& Henry, Y. (1994). The addition of glutamic acid or protein to a threonine-deficient diet differentially affects growth performance and threonine dehydrogenase activity in fattening pigs. Journal of Nutrition 124, 1987-1995.

Le Floc'h, N., Obled, C. \& Sève, B. (1995). In vivo threonine oxidation is dependent on threonine dietary supply in growing pigs fed low to adequate levels. Journal of Nutrition 125, 2550-2562.

Read, W. W., Read, M. A., Rennie, M. J., Griggs, R. C. \& Halliday, D. (1984). Preparation of $\mathrm{CO}_{2}$ from blood and protein-bound carboxyl groups for quantification and ${ }^{13} \mathrm{C}$-isotopes measurements. Biomedical Mass Spectrometry 11, 348-352.

Rérat, A., Simoes-Nuñes, C., Mendy, F., Vaissade, P. \& Vaugelade, P. (1992). Splanchnic fluxes of amino acids after duodenal infusion of carbohydrate solutions containing free amino acids or oligopeptides in the nonanaesthetized pig. British Journal of Nutrition 68, 111-138.

Rosell, V. L. \& Zimmerman, D. R. (1984). Effects of excess arginine and threonine on performance, plasma metabolites and certain liver enzyme activities in weanling pigs. Nutrition Reports International 29, $1345-1351$.

Shipley, R. A. \& Clark, R. E. (1972). Tracer Methods for In Vivo Kinetics. Theory and Applications. New York: Academic Press.

Statistical Analysis Systems (1989). SAS User's Guide: Statistics. Cary, NC: SAS Institute Inc.

Tressel, T., Thompson, R., Zieske, L. R., Menendez, M. I. T. S. \& Davis, L. (1986). Interaction between Lthreonine dehydrogenase and aminoacetone synthetase and mechanism of aminoacetone production. Journal of Biological Chemistry 261, 16428-16437.

Zhao, X., Wen, Z. M., Meredith, C. E., Matthews, D. E., Bier, D. M. \& Young, V. R. (1986). Threonine kinetics at graded threonine intakes in young men. American Journal of Clinical Nutrition 43, 795-802. 